\title{
The Politics of Crowding in California's Prisons
}

Forrest Lee Jones

\section{INTRODUCTION}

California prisons are so severely crowded that the United States Supreme Court has found that the state cannot deliver adequate medical care to prisoners. Thus, California prison living conditions are in violation of the United States Constitution's Eighth Amendment ban on cruel and unusual punishment. Because of this finding, the court has ordered the state to cap its prisons at 137.5 percent of designed capacity. However, Governor of California, Jerry Brown, has hindered, delayed, and downright refuses to follow the spirit of the ruling, claiming doing so would endanger public safety. This article discusses the various barriers to reform, the consequences of chronic prison crowding and charts a way forward on how to address this issue going forward.

\section{BARRIERS TO REFORM}

Behind the curtain of public safety are election year politics. Governor Brown does not want to look soft on crime and the influence of powerful special interests groups, such as the California Correctional Peace Officers Association (CCPOA) are opposed to releasing prisoners (Page, 2011). This tug-a-war between doing what the Court said, add dignity to the life of the incarcerated by capping the prison population at manageable levels, and the ongoing violations and deteriorations of both the medical and mental health conditions in California prisons are human beings with no recourse other than the courts. That being said, crowding and the lack of adequate medical care is a result of overly punitive laws and the influence of vested interest groups that conditions for confinement are unconstitutional (i.e. inhumane) and that these unconstitutional conditions are the principle reason for the unconscionable and preventable per week death that is plaguing the California prison system. With all this, public opinion has never sided with the criminal class regardless of any change or rehabilitative efforts done by the many men and women who have turned their lives around.

Since 2009, the State of California has been under a federal court order to reduce its prison population from 160,000 to 112,000 . Now that California Department of Corrections and Rehabilitation is within a few thousand prisoners of the court-mandated cap, Governor Brown has won a 
two-year extension to reach the cap. He has until 28 February 2016 to cap California's prisons at 137.5 percent of design capacity. The Governor's plan may accomplish this through various measures, such as transferring prisoners to private lockups, increasing conduct credits, and releasing medically ill and older prisoners. What is not included in Brown's plan is sentencing reform of state laws that has contributed to the crowding problems in the first place.

California prisons are crowded due to mandatory minimum laws like the Three-Strikes provisions and legislative measures that enhance sentences under certain circumstances. Special interest groups like the CCPOA support such laws and exert strong influence over the Governor and Legislature to keep them coming. The CCPOA in 2010 contributed $\$ 1.2$ million to Brown's run for Governor and Brown in return gave the CCPOA a lavish pay raise in 2012 (see PLN, 2012). The CCPOA works to keep laws intact and oppose sentencing reform. Additionally, private prison companies like Corrections Corporation of America have a stake in California prisons. A study done by Service Employees International Union (SEIU) on corporate Mega-Contracts in California State Government showed the State spent a whopping \$210.6 billion dollars for the services of 25 vendors between the period of 2003 and 2010 (SEIU Local 1000, 2012). The state spent $\$ 1,315,023,163$ for the services of Corrections Corporation of America (CCA), which provides out of state housing facilities for California prisoners. In turn, the CCA spent $\$ 300,000$ on lobbying the state legislature for more out-ofstate beds and legislation to house illegal immigrants. In 2000, there were 26 for-profit prison corporations in the United States, operating approximately 150 facilities in 28 states. The largest of these companies, CCA, controls 76.4 percent of the private prison market globally (Davis, 2003). Alexander (2010) reported on "The Bill Moyers Show" that governors across the United States were told by private prison corporations to keep their prisons at 90 percent capacity so that they can do business with them. Special interest groups, like the CCPOA and CCA, support the prison industrial complex because it provides job security, increased wages, union dues and benefits. These special interest groups oppose sentencing reform to reduce the prison population, which is a speedier and viable way to bring California medical and mental health to constitutional standards for state prisoners. 


\section{CONSEQUENCES}

During the two-year extension period that the state has to cap its prisons, prisoners will continue to live under abysmal unconstitutional conditions, even though the state has the means under state law to comply with the population cap right now. The state has reduced crowding at some prisons, but it persists in many other facilities. Some are packed to as much as 178 percent of designed capacity. Just recently, the state missed its benchmark deadline of 30 June 2014 to reduce the population to 143 percent design capacity by several hundred prisoners because it attempted to count unused beds at its most recently opened prison/medical facility in Stockton California. The court ordered the state not to count the beds until they could properly manage them. This counting debacle comes in the wake of a sick prisoner dying in the new so-called hospital earlier this year for reasons that are still not completely clear.

The crowded conditions at San Quentin State Prison have increased the time for a prisoner to be seen by a physician from a few weeks to a few months. Crowding is even affecting my living conditions. I live in a cell built for one. However, the cell houses two people. The cell is so small that you cannot fully extend your arms without hitting the walls. It complicates living conditions by creating a congested environment, there are excessive smells, and it is difficult to manoeuver everywhere inside the housing units, which sometimes creates tension resulting in altercations between prisoners. 1 know a prisoner who hates living with his cellmate and purposely initiates altercations with him. Consequently, it resulted in him being removed from the general population, thus increasing his prison sentence. This is a vicious cycle created by the crowded conditions that the courts are ordering the state to fix, all the while, the state continues to use stall tactics. Another prisoner, by the name of Richard Bess, has been incarcerated more than 20 years suffered just recently from inadequate treatment by the California Men's Colony prison staff. This prisoner was experiencing blood in his urine for seven months. After seeing the doctors, he was told he had urine tract infection. Bess came to learn later his condition was misdiagnosed and the doctors discovered he had cancer in his bladder. Mr. Bess later died from his condition in 2012. Appointments with his doctor were prolonged and cancelled. These conditions alone create a state of conflict, interfering with a dignified state of living of the human beings under this type of subjugation. 
Central California Women's Facility (CCWF) is another example of the state's dismal record when it comes to forcing its prisoner population to live in crowded conditions. CCWF is the result of closing one of three California women's prisons. CCWF is currently operating at 178.5 percent of designed capacity, and is "not providing adequate medical care" (Objections to Defendants January 23, 2014 Proposed Order in Plata v. Brown, Case No. Civ. S900520 LKK-JEM P, Co 1-1351 dated 1/28/14). The result is "preventable morbidity and mortality" and "an on-going serious risk of harm to patients" (ibid). Court appointed experts said, "The majority of problems are attributable to overcrowding, insufficient health care staffing, and inadequate medical bed space" (ibid). The court has evaluated nine other prisons since mid-March 2013 and did not find any that were providing adequate care. At the five other prisons, the experts' overall conclusion, like that of CCWF, was that adequate care is not being provided and that "systemic issues...present an on-going serious risk of harm to prisoners and results in disease and death". At three other prisons, the experts concluded the institutions would only provide "adequate medical care once...health care physical plant issues are corrected" (ibid, p. 3).

The Plata court experts described how one prisoner was evidently in distress on the floor outside his cell, complaining of abdominal pain, flailing his arms, and stating he was unable to walk - he was abandoned by nurses and a physician notified of the situation refused to see the patient. Several hours later, he was found unresponsive and custody staff failed to initiate CPR. The prisoner died that same day. In another case, a urologist, after considering a patient's very elevated lab results, recommended a biopsy to rule out cancer. More than two months later the prisoner had not seen a doctor for follow-up, the biopsy had not occurred and there was no documentation that it had been considered. The patient died due to the state's failure to identify his cancer.

Prisoners with mental illness continued to suffer the devastating effects of on-going crowding in California prisons (see Dey, 2013). Grossly inadequate mental health care and delayed access to higher levels of care and psychiatric hospitalization, coupled with extended and unnecessary placements in dangerous segregation units, exacerbate the situation. Overall reductions have not trickled down to the mental health patients. To cope with chronic shortages of crises beds and persistent waitlists for inpatient psychiatric hospitalization, the state continues to place prisoners suffering 
acute psychiatric distress into makeshift, unlicensed units and unsafe alternative housing cells. Prisoners with mental illness are routinely held for long durations in dangerous segregation units, where they are subjected to treatment in cages and blanket strip searches, merely because the state lacks safe and appropriate housing alternatives. Mental health treatment is still delivered in non-confidential, anti-therapeutic spaces, such as cages and converted storage closets, and primary clinician contacts frequently take place through the doors of locked cells.

Despite these deplorable conditions and the increasing rates of suicide in California prisons, the State has elected to cancel and delay critical projects to expand mental health treatment space for prisoners with mental illness. Most recently, the state notified the federal three judge panel that the long-planned activation of California Health Care Facility has been further delayed on account of the state's inability to recruit psychiatrists to staff the facility. Staffing shortages are endemic among mental health clinicians and access-to-care officers, and further diminish the sufficiency of treatment for mentally ill prisoners. The court has also expressed "grave concern" about the state's continued failure to address foreseeable and preventable suicides, which continue at staggering rates throughout the CDCR prisons while the state delays its efforts to reduce crowding.

\section{MORE OF THE SAME AND WAYS FORWARD}

In light of these serious and ongoing constitutional violations, granting the State a two-year extension of time will inevitably result in incalculable suffering. This continued suffering can be avoided, however, by requiring the state to reform their laws, which will adequately reduce the prison population to constitutional standards. However, this reform cannot easily be addressed because of the politics described in this essay, resulting in prisoners' continued suffering. Both the United States Supreme Court in their 2011 opinion affirming the Three Judge panel 2009 population reduction order found that various available methods of reducing crowding would have little or no impact on public safety. The court found expanding good time credits would allow the State to give early release to only those prisoners who pose the least risk of coming into conflict with the law again.

In spite of all these difficulties California prison officials have reaching the cap, the Department of Corrections and Rehabilitation project the state's 
prison population to grow by over 6,000 prisoners by 2019 (CDCR, 2013, p. 2). The crowding problems in California's prisons could get worse, not better. I will conclude with statements by Little Hoover Commission (2014) Chairman Jonathan Shapiro that capture the current state of affairs and the need for fundamental change:

California's correctional system is a slow-motion disaster... The prison population reduction cannot be achieved without eliminating the state's chronic imbalance between what its sentencing laws require and the resources available to incarcerate offenders... taxpayers do not want to pay for failed policies that cycle offenders in and out of prison or incarcerate the mentally ill and the addicted for lengthy sentences without access to quality treatment. Research has shown programs and services that provide treatment can be effective in reducing crime... Scientific research in the past 40 years has led to significant progress in many areas in California. When it comes to criminal justice sentencing, however, California has ignored the science.

In light of these words, one cannot help but think that the (in)action of "Golden State" criminal justice policymakers on this matter are, to put it generously, negligent.

\section{REFERENCES}

Alexander, Michelle (2010) The New Jim Crow: Mass Incarceration in the Age of Colorblindness, New York: The New Press.

California Department of Corrections and Rehabilitation [CDCR] (2013) "Fall 2013 Adult Population Projections", Sacramento. Retrieved from $<$ http://www.cdcr.ca.gov/ Reports_Research/Offender_Information_Services_Branch/Projections/F13pub.pdf $>$. Davis, Angela (2003) Are Prisons Obsolete?, New York: Seven Stories Press.

Dey, Eugene (2013) “A Requiem for Freddy", Journal of Prisoners on Prisons, 22(2): 15-21.

Little Hoover Commission (2014) Sensible Sentencing for a Safer California, Sacramento. Retrieved from <http://www.lhc.ca.gov/studies/219/report219.html $>$.

Page, Joshua (2011) The 'Toughest Beat': Politics, Punishment, and the Prison Officers' Union in California, New York: Oxford University Press.

Prison Legal News [PLN] (2012) "California Governor Cozies up to Prison Guards and Crime Victim Advocates" - February 15. Retrieved from < https://www. prisonlegalnews.org/news/2012/feb/15/california-governor-cozies-up-to-prisonguards-and-crime-victim-advocates/>. 
Service Employees International Union [SEIU] Local 1000 (2012) The Hidden Branch of Government: Corporate Mega-Contracts in California State Government, Sacramento. Retrieved from <http://seiu1000.org/whitepapers/State_Contracting web.pdf $>$.

\section{ABOUT THE AUTHOR}

Forrest Lee Jones is incarcerated at San Quentin State Prison in California. He can be contacted at:

Forrest Lee Jones, E89706

San Quentin State Prison

Facility E. W. 77 Low

San Quentin, California 94964

USA 